I found Political Reconciliation to be in roughly equal measure enjoyable, stimulating and frustrating. This last reaction in large part reflects my resistance to Arendt, and no doubt those who are more responsive to her work, are likely to be more in tune with Schaap's approach. But, even while hoping that he will break free from his current subservience to her work, this should not obscure the other two responses.

John Horton

Keele University, Staffs, UK.

\title{
Genealogies of Difference
}

Nathan Widder

University of Illinois Press, Chicago, 2002, ix $+190 p p$.

ISBN: 0252027078.

Contemporary Political Theory (2007) 6, 112-113. doi:10.1057/palgrave.cpt.9300266

Genealogies of Difference is precisely that. Widder takes the post-Nietzschean, anti-foundational concepts of difference, excess and contingency and re-reads the history of philosophy through those terms. The object is not to make philosophy produce this telos, but rather to explore what those conceptions might mean for us, and do for us, in a social world where absolutes and binaries are refused. In this postmodern condition, differences are exposed and celebrated as a matter of good practice by liberal egalitarians, not just by anarchists, and philosophy needs to catch up.

Given that God is dead, Kantian transcendence deconstructed, and Hegelian resolutions overthrown, what is there for philosophy, and in particular ethics, to do? For Widder, the answer is that philosophy and ethics don't give answers, but rather pointers as to what to avoid, what not to believe, what not to expect and what not to strive for. In our latter-day world, we should expect the 'untimely', that is, the unpredictable that exposes the imposed and safety-seeking strategies of historical and logical linearity, closure and wholeness. Moreover, we should find a way of producing this unpredictability strategically. Widder's outlook on philosophy is thus an 'affirmation of difference' (p. 56).

In his conclusion, Widder notes that his 'ontological rethinking of difference thus comes to have ethical and political import', and that this is a 'matter not escaping games of truth but rather of playing them differently'. On his view ethics and politics require a 'sense of curiosity and care', which is perhaps rather more suggestive of Oscar Wilde ('in matters of grave importance, style, not sincerity, is the vital thing') than of philosophy as traditionally practised (p. 154). 
While not disagreeing with this line of thought and even celebrating its tenacious refusal of metaphysical certainty, I have a number of questions about the study itself that readers (and the author?) might like to consider.

(1) To what extent is the book about developing the (anti?) philosophical (political?) strategy that Widder avers? Or to what extent is it a book about selected authors in the history of philosophy that re-explicates those thoughts for the sake of further scholarship?

(2) What is the (political?) strategy that Widder hints at in the conclusion? Or what would be an example of a politics consonant with it? or an ethics? Some indicative but deconstructive work on issues in the political world would be helpful, in what is otherwise a very abstract study.

(3) This book takes philosophy very seriously, but I'm not so sure it takes language seriously enough. Does Widder have a view about his philosophizing of difference as a range of more or less novel metaphor: excess, rhizome, fold, warp, out of joint, groundless difference, etc.? Or are these terms somehow descriptive (of what, exactly?)? Or are they performative - what things do they, or could they, help us do?

This book is highly recommended as a post-Nietzschean, pro-Deleuzean explication of a philosophical position, and it genuinely pushes political and ethical thought beyond good and evil into an intense engagement with non-binary concepts of difference. This is clearly differentiated from previous resolutions in philosophy that promised truth, certainty and redemption, and it does not amount to nihilism, refusal of judgement or cynicism. The scholarly work is erudite and should keep us busy for quite some time. However, I look forward to work from Widder that moves his project more obviously into the political realm.

Terrell Carver

University of Bristol, Bristol, UK.

\author{
Radical Space: Building the House of the People \\ Margarete Kohn \\ Cornell University Press, Ithaca and London, 2003, xii $+204 p p$. \\ ISBN: 0801439922.
}

Contemporary Political Theory (2007) 6, 113-117. doi:10.1057/palgrave.cpt.9300270

The main aim of this book is to demonstrate the centrality of space for politics. Focusing on spaces of 'radical democratic practice' in pre-fascist Italy, Margarete Kohn argues in particular for a better understanding of the role of spatial practices in transformative politics. She takes issue with Habermas' 